\title{
First insights into the genetic diversity of Mycobacterium tuberculosis isolates from HIV-infected Mexican patients and mutations causing multidrug resistance
}

Rocio Lopez-Alvarez ${ }^{1,2}$, Claudia Badillo-Lopez², Jorge F Cerna-Cortes², Ivan Castillo-Ramirez², Sandra Rivera-Gutierrez ${ }^{2}$, Addy C Helguera-Repetto ${ }^{2}$, Diana Aguilar ${ }^{3}$, Rogelio Hernandez-Pando 3 , Sofia Samper ${ }^{4}$, Jorge A Gonzalez-y-Merchand ${ }^{2^{*}}$

\begin{abstract}
Background: The prevalence of infections with Mycobacterium tuberculosis (MTb) and nontuberculous mycobacteria (NTM) species in HIV-infected patients in Mexico is unknown. The aims of this study were to determine the frequency of MTb and NTM species in HIV-infected patients from Mexico City, to evaluate the genotypic diversity of the Mycobacterium tuberculosis complex strains, to determine their drug resistance profiles by colorimetric microplate Alamar Blue assay (MABA), and finally, to detect mutations present in katG, rpoB and inhA genes, resulting in isoniazid (INH) and rifampin (RIF) resistance.

Results: Of the 67 mycobacterial strains isolated, 48 were identified as MTb, 9 as M. bovis, 9 as M. avium and 1 as M. intracellulare. IS6110-RFLP of 48 MTb strains showed 27 profiles. Spoligotyping of the 48 MTb strains yielded 21 patterns, and $9 \mathrm{M}$. bovis strains produced 7 patterns. Eleven new spoligotypes patterns were found. A total of 40 patterns were produced from the 48 MTb strains when MIRU-VNTR was performed. Nineteen (39.6\%) MTb strains were resistant to one or more drugs. One (2.1\%) multidrug-resistant (MDR) strain was identified. A novel mutation was identified in a RIF-resistant strain, GAG $\rightarrow$ TCG (Glu $\rightarrow$ Ser) at codon 469 of rpoB gene.

Conclusions: This is the first molecular analysis of mycobacteria isolated from HIV-infected patients in Mexico, which describe the prevalence of different mycobacterial species in this population. A high genetic diversity of MTb strains was identified. New spoligotypes and MIRU-VNTR patterns as well as a novel mutation associated to RIF-resistance were found. This information will facilitate the tracking of different mycobacterial species in HIVinfected individuals, and monitoring the spread of these microorganisms, leading to more appropriate measures for tuberculosis control.
\end{abstract}

\section{Background}

Tuberculosis (TB) remains the most common opportunistic infection for people living with human immunodeficiency virus (HIV), and a leading cause of death in low and middle-income countries [1]. The number of new TB cases has tripled in countries where the incidence of HIV is high in the last two decades [2]. At least one-third of the 33.2 million people living with HIV worldwide are infected with TB and have up to

\footnotetext{
* Correspondence: jgonzal1212@hotmail.com

${ }^{2}$ Departamento de Microbiologia, ENCB-IPN, Mexico City, Mexico
}

$15 \%$ risk of developing $\mathrm{TB}$ every year, compared to those without HIV who have a $10 \%$ risk over their lifetime [3]. In Mexico, HIV-infected patients account for $1.0 \%$ of new TB cases [4]. In other developing countries, it has been reported that in HIV-infected patients, Mycobacterium tuberculosis (MTb) is not the only mycobacteria that causes disease, nontuberculous mycobacteria (NTM) have also been found in such patients [5,6]. In Mexico identification of mycobacterial species is generally based on clinical features, sometimes with the help of a positive acid-fast stain [7]. 
Since the discovery of polymorphic DNA in MTb, molecular typing of strains has become a valuable tool in TB epidemiological studies allowing investigators to track epidemics, detect new outbreaks, and achieve better knowledge of strain movement distinguishing between reinfection and relapse [8]. IS6110 restriction fragment length polymorphism (RFLP) typing of MTb has been used extensively in studies of TB transmission and is one of the most widely applied and standardized molecular typing methods $[9,10]$. Spacer oligonucleotide typing (spoligotyping) is another molecular genotyping technique; it is fast, robust, reliable, easy to perform, and cost-effective [11]. Spoligotyping is based on the analysis of the direct repeat (DR) loci, which are comprised of directly repeated sequences interspersed with non-repetitive spacer DNA [11]. This rapid PCR-based method allows the classification of strains into spoligotype families based on the presence or absence of spacer regions [12,13]. The most promising PCR-based methods are based on the analysis of multiple loci containing variable numbers of tandem repeats (VNTR) of different families of interspersed genetic elements, collectively called mycobacterial interspersed repetitive units (MIRU) [14,15]. Currently, the most commonly used version of this method (designated MIRU-VNTR) is based on the analysis of 12 loci [16]. Some authors have found that this method shows a discriminatory power equivalent to that of RFLP and for this reason it has been considered an alternative method to IS6110-RFLP for epidemiological studies $[14,16,17]$. One of the most alarming trends concerning $\mathrm{TB}$ is the emergence of drug-resistant MTb strains, which have become a worldwide health care problem [18]. The number of multidrug-resistant strains of MTb (MDR-TB), defined as resistant to at least isoniazid (INH) and rifampin (RIF), has been steadily increasing over the years, and several outbreaks have been reported $[19,20]$. The development of resistance to these two drugs reduces the efficacy of standard antituberculosis treatment to $77 \%$. For this reason it is important to identify resistant strains as soon as possible to permit adjustments in treatment and minimize transmission of drug-resistant strains. Mutations in the catalase peroxidase gene (katG) [21,22] and in a gene encoding the enoyl acyl carrier protein reductase (inhA) [23] have been found to account for 60 to $70 \%$ and 10 to $15 \%$ of INH-resistant MTb strains, respectively [24]. Mutations resulting in a single amino acid change within the 81 -bp core region of the RNA polymerase $\beta$-subunit (rpoB) gene are found in $96 \%$ of RIF-resistant MTb strains [25].

The aims of this study were to determine the prevalence of mycobacterial species in HIV-infected patients from Mexico City and surrounding areas, to evaluate the genotypic diversity of the Mycobacterium tuberculosis complex (MTC) strains using IS6110 RFLP, spoligotyping and MIRU-VNTR, to determine their drug resistance profiles, and to detect mutations present in $k a t \mathrm{G}$, inh $\mathrm{A}$ and $r p o \mathrm{~B}$ genes that lead to the selection of INH- and RIF-resistant strains.

\section{Results}

\section{Mycobacteria prevalence in HIV-infected patients}

In this study we characterized 67 mycobacterial strains isolated from HIV-infected patients, $85 \%$ of strains belonged to the MTC; 48 (71.6\%) were MTb, 9 (13.4\%) $M$. bovis, and the remaining 15\% were NTM: 9 (13.4\%) corresponded to M. avium and $1(1.5 \%)$ to M. intracellulare. Thirty MTb strains (62.5\%) were isolated from pulmonary specimens, while 8 of $9 \mathrm{M}$. avium strains (89\%) were isolated from extrapulmonary specimens. Thirteen patients presented more than one site of infection (see Table 1).

\section{RFLP analysis}

RFLP analysis of all MTb strains was performed using IS6110 as probe. The IS6110 fingerprint patterns generated were highly variable. The number of IS6110 copies per strain varied from 0 to 14 . Of IS6110 fingerprint patterns observed, 19 (39.6\%) were unique, indicating epidemiological independence (Figure 1), and 10 strains (20.8\%) lacked IS6110 (zero copy number). These patterns (zero IS6110 bands) were confirmed by performing a second RFLP analysis where MTb H37Rv was included as control strain. Additionally, 19 strains (39.6\%) were clustered in 8 groups consisting of 2 to 3 strains with identical IS6110 RFLP patterns, presumably representing cases of recent transmission, and 16 (33.3\%) strains presented IS6110 RFLP patterns with five bands or fewer.

\section{Spoligotyping}

To determine lineage, the 57 strains (48 $\mathrm{MTb}$ and 9 M. bovis) from the MTC were spoligotyped and binary outcomes were compared with the shared type (ST) number and lineages and sublineages reported by Brudey et al [26]. Spoligotype analysis of $48 \mathrm{MTb}$ strains yielded 21 patterns (Figure 1). Thirty-nine MTb strains $(81.3 \%)$ were grouped into 12 clusters (2 to 10 strains per cluster) while 9 strains showed unique patterns. Thirty-four MTb strains showed 12 spoligotyping patterns that matched with: Shared-type (ST) number 2 (lineage name H2; $\mathrm{n}=1$ ), ST42 (LAM9; $\mathrm{n}=10$ ), ST47 $(\mathrm{H} 1 ; \mathrm{n}=2)$, ST50 (H3; n = 2), ST53 (T1; n = 5), ST119 $(\mathrm{X} 1 ; \mathrm{n}=3), \operatorname{ST} 137(\mathrm{X} 2 ; \mathrm{n}=2), \operatorname{ST} 274(\mathrm{U} ; \mathrm{n}=1)$, ST508 (T1; n = 4), ST732 (T1; n = 2), ST948 (H3; $\mathrm{n}=1)$, and ST1626 (T1; n = 1). A further $14 \mathrm{MTb}$ strains showed 9 patterns that did no exist in the SpolDB4.0 database (see question marks, Figure 1). Spoligotyping allows discrimination of MTb strains with 
Table 1 Genomic patterns of mycobacterial strains isolated from different clinical samples of the same patient

\begin{tabular}{|c|c|c|c|c|c|c|}
\hline Patient & $\begin{array}{l}\text { Strain } \\
\text { code }\end{array}$ & Clinical sample & $\begin{array}{c}\text { Mycobacterial } \\
\text { specie }\end{array}$ & $\begin{array}{c}\text { Spoligotyping Share type (ST) } \\
\text { number }\end{array}$ & $\begin{array}{l}\text { RFLP } \\
\text { cluster }\end{array}$ & $\begin{array}{c}\text { MIRU-VNTR (code } \\
\text { number) }\end{array}$ \\
\hline \multirow[t]{2}{*}{1} & IPN 24 & Pleural effusion & MTb & ST42 & 16 & $23^{\prime} 3216153321$ \\
\hline & IPN 25 & urine & MTb & ST42 & 16 & 225225153323 \\
\hline \multirow[t]{2}{*}{2} & IPN 29 & Urine & MTb & ST732 & 12 & 220326153322 \\
\hline & IPN 31 & Sputum & MTb & ST732 & 12 & 223326153322 \\
\hline \multirow[t]{2}{*}{3} & IPN 64 & Urine & MTb & ST119 & 9 & 223224153323 \\
\hline & IPN 67 & $\begin{array}{l}\text { Bronchoalveolar lavage } \\
\text { fluid }\end{array}$ & MTb & ST119 & 10 & $23^{\prime} 3226133321$ \\
\hline \multirow[t]{2}{*}{4} & IPN 69 & Urine & MTb & $?^{\text {h }}$ & 23 & 332226153322 \\
\hline & IPN 70 & $\begin{array}{l}\text { Bronchoalveolar lavage } \\
\text { fluid }\end{array}$ & MTb & $?^{\mathrm{h}}$ & 23 & 225223153322 \\
\hline \multirow[t]{2}{*}{5} & IPN 74 & Urine & MTb & ST50 & 1 & 223225123322 \\
\hline & IPN 75 & Sputum & MTb & ST50 & 1 & 224325153324 \\
\hline \multirow[t]{3}{*}{6} & IPN 10 & Bone marrow & MTb & ST42 & 15 & $23^{\prime} 3226133321$ \\
\hline & IPN 11 & Sputum & MTb & ST42 & 15 & 225225153323 \\
\hline & IPN 12 & $\begin{array}{l}\text { Bronchoalveolar lavage } \\
\text { fluid }\end{array}$ & MTb & ST42 & 15 & 225226143323 \\
\hline \multirow[t]{3}{*}{7} & IPN 15 & Pleural effusion & MTb & $?^{\mathrm{b}}$ & $\bullet$ & 223326133321 \\
\hline & IPN 16 & Sputum & MTb & $?^{\mathrm{b}}$ & $\bullet$ & 223326133321 \\
\hline & IPN 17 & Gastric fluid & MTb & $?^{\mathrm{b}}$ & $\bullet$ & 223226133322 \\
\hline \multirow[t]{3}{*}{8} & IPN 85 & Bone marrow & MTb & ST508 & 8 & 220225150020 \\
\hline & IPN 86 & $\begin{array}{l}\text { Bronchoalveolar lavage } \\
\text { fluid }\end{array}$ & MTb & ST508 & 8 & 223225153321 \\
\hline & IPN 87 & Sputum & MTb & ST508 & 8 & 220005153320 \\
\hline \multirow[t]{2}{*}{9} & IPN 43 & Pleural effusion & M. bovis & ST1306 & ND & 232224253322 \\
\hline & IPN 99 & Lymph node & M. bovis & ST1625 & ND & 232224253322 \\
\hline \multirow[t]{3}{*}{10} & IPN 56 & Urine & M. bovis & ST409 & ND & 232224153323 \\
\hline & IPN 57 & Sputum & M. bovis & ST409 & ND & 222224053320 \\
\hline & IPN 58 & Cerebrospinal fluid & M. bovis & $?^{i}$ & ND & 232224253322 \\
\hline \multirow[t]{4}{*}{11} & IPN 46 & Cerebrospinal fluid & M. bovis & ST683 & ND & 232224152320 \\
\hline & IPN 47 & Cerebrospinal fluid & M. bovis & ST479 & ND & 332224153322 \\
\hline & IPN 48 & Gastric fluid & M. bovis & $?^{\mathrm{j}}$ & ND & 232225153322 \\
\hline & IPN 49 & Sputum & M. bovis & ST479 & ND & 332225153322 \\
\hline \multirow[t]{2}{*}{12} & IPN 1 & Bone marrow & M. avium & ND & ND & ND \\
\hline & IPN 3 & Gastric fluid & M. avium & ND & ND & ND \\
\hline \multirow[t]{2}{*}{13} & IPN 41 & Bone marrow & M. avium & ND & ND & ND \\
\hline & IPN 60 & Lymph node & M. avium & ND & ND & ND \\
\hline
\end{tabular}

MTb, M. tuberculosis. ND, No determined, ? ${ }^{\mathrm{b}}$, Spoligotype octal, $777743677760771, ?^{\mathrm{h}}$, Spoligotype octal 777777660000131 , ?', Spoligotype octal 264063776776600 , ?', Spoligotype octal $677767777777600, \bullet, M$. tuberculosis strains with zero-copy-numbers of IS6110. 


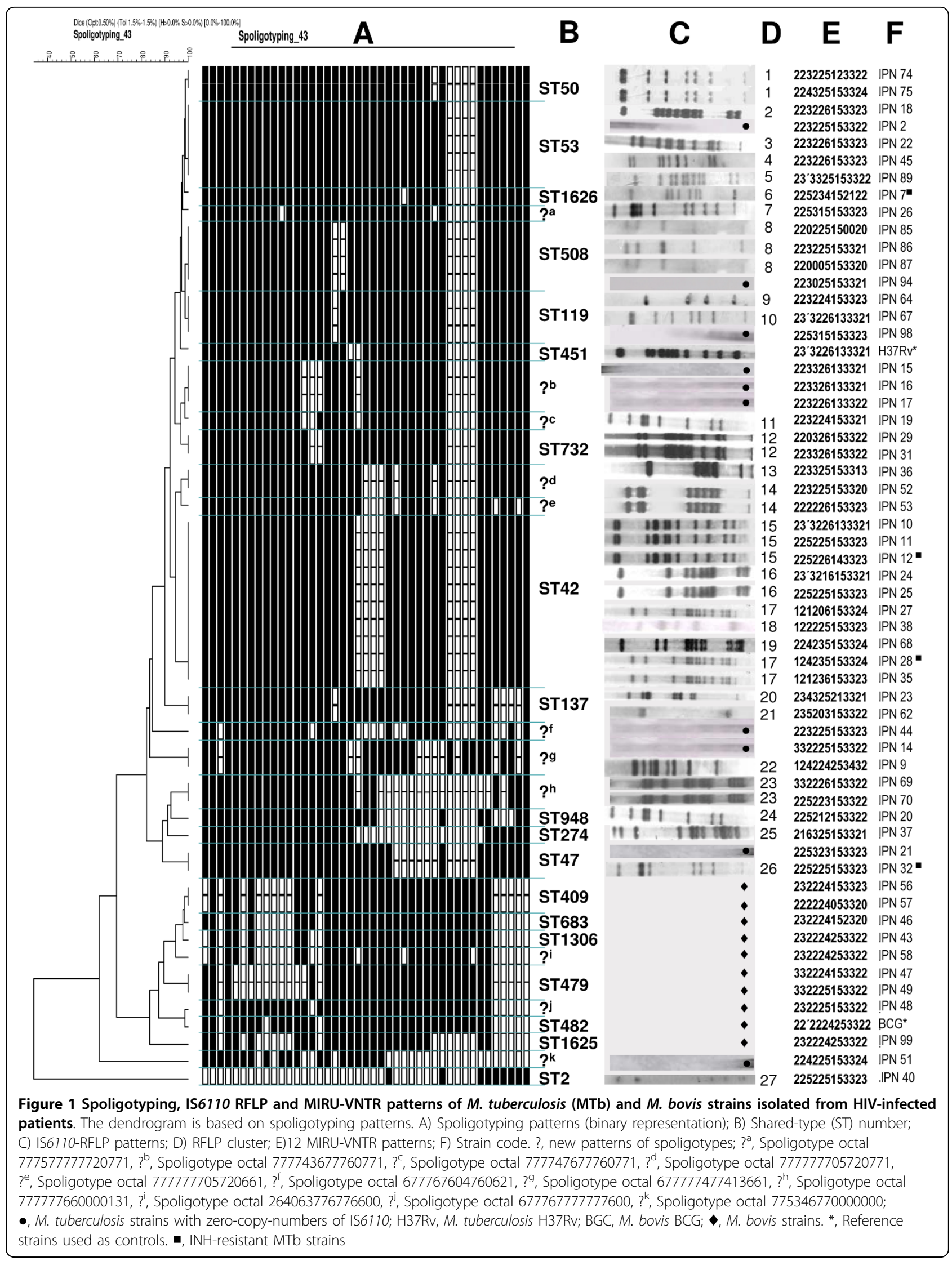


low-copy-numbers of IS6110 (see Figure 1; for example, strains MEX-IPN 15, MEX-IPN 16, MEX-IPN17 and MEX-IPN 44). Nine $M$. bovis strains yielded 7 spoligotyping patterns; 5 unique patterns and 2 clusters with 2 strains in each one (Figure 1). The M. bovis spoligotyping patterns matched with ST409 (BOVIS2; $\mathrm{n}=2$ ), ST479 (BOVIS3; $\mathrm{n}=2$ ), ST683 (BOVIS2; $\mathrm{n}=1$ ), ST1306 (BOV; $\mathrm{n}=1$ ), ST1625 (BOVIS2; $\mathrm{n}=1$ ), and 2 new patterns were identified (Figure 1).

\section{MIRU-VNTR patterns}

Clustering of MIRU-VNTR patterns by the UPGMA method showed a greater diversity of patterns in the mycobacterial strains studied. A total of 40 patterns were produced from $48 \mathrm{MTb}$ strains, 5 clusters were identified ( 2 clusters with 4 and 3 strains, respectively, and 3 clusters with 2 strains in each). The remaining 35 strains showed unique patterns. Nine $M$. bovis strains produced a total of 7 patterns (Figure 1), 1 cluster was identified with 3 strains, while 6 strains presented unique patterns.

\section{Genomic diversity of MTb isolates}

The discriminatory power of MIRU-VNTR typing was compared to that of IS6110 RFLP and spoligotyping by analyzing only MTb strains. Overall, MIRU-VNTR typing discriminated 40 different patterns (Figure 1); in comparison, only 27 different patterns were obtained with IS6110 RFLP and 21 patterns were obtained with spoligotyping. MIRU-VNTR typing performed even better than a combination of spoligotyping and IS6110 RFLP, which discriminated 36 patterns. The maximal discrimination was apparently achieved by combining MIRU-VNTR and IS6110 RFLP typing, resulting in 46 patterns.

Spoligotypes could often be distinguished by MIRUVNTR typing; for instance, the single ST42 spoligotype corresponded to 9 distinct MIRU-VNTR genotypes (Figure 1). By contrast, just three of the MIRU-VNTR patterns (225225153323, 23'3226133321 and 225315153323) were distinguished by spoligotyping.

\section{Genomic patterns of mycobacterial strains isolated from the same patient}

Identical spoligotyping and RFLP patterns were found among each set of strains in 7 out of 8 patients that were infected with more than one MTb strain (Table 1; patients 1, 2, 4-8). Only one patient (patient 3) had two strains that differed in both, RFLP and MIRU-VNTR typings, suggesting that, this particular patient was infected with two different strains of MTb. Regarding M. bovis strains, patients 9,10 and 11 (Table 1) were infected with 2, 3 and 4 different strains according to their spoligotyping and MIRU-VNTR typing. Each of patients 12 and 13 were infected with two M. avium strains; but whether these are different strains remains to be determined.

\section{Phenotypic drug resistance testing}

A total of 57 strains (48 MTb and $9 \mathrm{M}$. bovis) were subjected to colorimetric microplate Alamar Blue assay (MABA). Testing indicated that $9 \mathrm{M}$. bovis strains were susceptible to the 4 drugs tested, while 19 (39.6\%) MTb strains showed resistance to one or more drugs (Table 2). Only one (2.1\%) MTb strain was MDR, and 18 (95\%) of them were resistant to STR. As none of M. bovis strains showed resistance to the 4 antibiotics tested, no further characterization was carried out on them. No phenotypic or genotypic drug resistance tests were carried out in NTM.

\section{Genotypic drug resistance testing}

Mutations in katG, inhA and rpoB associated with resistance were found in $5(10.4 \%)$ MTb strains. Our study shows that strains isolated from HIV-infected patients not only have mutations in regions of genes previously shown to be involved in drug resistance, but also have mutations that have not been previously reported. The nucleotide and amino acid changes identified in the drug resistant strains are shown in the Table 3. Among the INH-resistant strains, 3 strains had a mutation

Table 2 Drug resistance of $M$. tuberculosis (MTb) strains isolated from HIV-infected patients

\begin{tabular}{|c|c|}
\hline Drug resistance $^{a}$ & No. (\%) of strains \\
\hline$\frac{\text { M. bovis }}{\text { Total strains }}$ & $9(100)$ \\
\hline Non-resistant strains & $9(100)$ \\
\hline$\frac{\text { M. tuberculosis }}{\text { Total strains }}$ & $48(100)$ \\
\hline Non-resistant strains & $29(60.4)$ \\
\hline Strains resistant to one or more drugs & 19 (39.6) \\
\hline \multicolumn{2}{|l|}{ Resistance to one drug only } \\
\hline STR & $12(25)$ \\
\hline EMB & $1(2.1)$ \\
\hline \multicolumn{2}{|l|}{ Resistance to more than one drug } \\
\hline INH, STR & $2(4.2)$ \\
\hline RIF, STR & $1(2.1)$ \\
\hline STR, EMB & $1(2.1)$ \\
\hline INH, STR, EMB & $1(2.1)$ \\
\hline INH, RIF, STR, EMB & $1(2.1)$ \\
\hline
\end{tabular}

${ }^{\mathrm{a}} \mathrm{INH}$, isoniazid; RIF, rifampin; STR, streptomycin; EMB, ethambutol. 
Table 3 Mutations found in M. tuberculosis (MTb) strains resistant to rifampin and isoniazid

\begin{tabular}{|c|c|c|c|}
\hline \multicolumn{4}{|l|}{ Rifampin } \\
\hline $\begin{array}{l}\text { Mutated } \\
\text { rpoB codon }\end{array}$ & $\begin{array}{l}\text { Specific } \\
\text { mutation }\end{array}$ & $\begin{array}{c}\text { Strain } \\
\mathrm{n}\end{array}$ & $\begin{array}{c}\mathrm{MIC} \\
(\mu \mathrm{g} / \mathrm{ml})\end{array}$ \\
\hline 531 & $\mathrm{TCG} \rightarrow \mathrm{TTG}(\mathrm{Ser} \rightarrow \mathrm{Leu})^{\mathrm{a}}$ & 1 & $>2$ \\
\hline 469 & $\mathrm{GAG} \rightarrow \mathrm{TCG}(\mathrm{Glu} \rightarrow \mathrm{Ser})^{\mathrm{b}}$ & 1 & 0.5 \\
\hline \multicolumn{4}{|l|}{ Isoniazid } \\
\hline $\begin{array}{l}\text { Mutated } \\
\text { katG codon }\end{array}$ & $\begin{array}{l}\text { Specific } \\
\text { mutation }\end{array}$ & $\begin{array}{c}\text { Strain } \\
\mathrm{n}\end{array}$ & $\begin{array}{c}\text { MIC } \\
(\mu \mathrm{g} / \mathrm{ml})\end{array}$ \\
\hline 315 & $\mathrm{AGC} \rightarrow \mathrm{ACC}(\mathrm{Ser} \rightarrow \mathrm{Thr})^{\mathrm{a}}$ & 3 & $>1$ \\
\hline 315 & $\mathrm{AGC} \rightarrow \mathrm{ACC}(\mathrm{Ser} \rightarrow \mathrm{Thr})$ & 1 & 1 \\
\hline
\end{tabular}

${ }^{a}$ Mutations found in the MDR M. tuberculosis strain

${ }^{\mathrm{b}}$ Mutation not described previously

$\mathrm{AGC} \rightarrow \mathrm{ACC}$ at codon 315 of $k a t \mathrm{G}$ gene (Ser $\rightarrow$ Thr), corresponding to the most common mutation found in INH-resistant strains $[27,28]$. The MDR strain had substitution mutations $\mathrm{AGC} \rightarrow \mathrm{ACC}$ (Ser $\rightarrow$ Thr) at codon 315 of $k a t G$ and TCG $\rightarrow$ TTG, at codon 531 of the rpoB gene, resulting in a predicted amino acid change of Ser $\rightarrow$ Leu. One RIF-resistant isolate had a mutation GAG $\rightarrow$ TCG (Glu $\rightarrow$ Ser) at codon 469 of the rpoB gene that has not been described previously. There was no correlation between the mutations and genotyping patterns of different strains in this study, i.e. the INHresistant MTb strains (IPN7, IPN12, IPN28 and IPN32) had the same substitution mutation AGC $\rightarrow$ ACC (Ser $\rightarrow$ Thr) at codon 315 of the katG gene, however they differ in the spoligotyping, IS6110 RFLP and MIRUVNTR patterns (see Figure 1 and Table 3).

\section{Discussion}

In this study we analyzed 67 mycobacterial strains isolated from HIV-infected patients attending different hospitals in Mexico City. Diagnosis of mycobacterial infection in Mexico is based on clinical symptoms with Ziehl-Neelsen staining (AFB) being the only laboratory confirmation of infection currently in use. Many patients are treated for MTb purely on the basis of a positive AFB test and in most cases strains are not tested for NTM due to the procedure for this characterization being lengthy and expensive. The incomplete identification of mycobacterial species producing infection can have serious consequences, resulting in longer hospitalization times, increased risk of nosocomial infections and selection of MDR strains. Delayed diagnosis is a key factor contributing to the unnecessary deaths of many people living with HIV. More importantly proper identification of mycobacterial species causing infection leads to more appropriate antimicrobial treatment [29]. In agreement with results from a previous study by Molina-Gamboa et al [7], we found thatMTb was the most prevalent mycobacterial species identified in HIVpatient samples investigated in this study. Of the 9.27 million patients globally-infected with MTb in 2007, an estimated 1.37 million (14.8\%) were HIV positive [30]. At least one-third of the 33.2 million people living with HIV worldwide are infected with $\mathrm{TB}$ and individuals infected with HIV are 20 to 30 times more likely to develop TB than those without the virus [2]. Although $\mathrm{MTb}$ is the most important etiological agent of TB, $M$. bovis, can also be considered a potential cause of human cases, especially in developing countries where control measures for bovine TB in cattle and/or milk dairy products are not always satisfactory [31]. With the advent of HIV, bovine TB represents an additional risk for HIV-infected patients. Importantly, pulmonary or extrapulmonary TB caused by $M$. bovis, may be underestimated due to the fact that the resulting infection is clinically indistinguishable from that caused by MTb. In this study $13.4 \%$ of strains isolated were identified as $M$. bovis. Our results are consistent with those reported by Cicero et al [32], who also identified $M$. bovis in extrapulmonary samples (13.75\%) from HIV-infected patients in Mexico. In an earlier study, Molina-Gamboa et al [7] identified M. bovis in $4.6 \%$ of patients with HIV using only biochemical tests.

Although in the past two decades NTM infections have been regarded as a growing concern, mainly as a result of the AIDS epidemic, these microorganisms were first recognized in the 1950s when the prevalence of TB fell after the introduction of antimycobacterial therapy [33]. NTM produce both pulmonary and extrapulmonary disease in both immunocompetent and immunocompromised subjects [33]. In this study, $15 \%$ of isolated mycobacterial strains were NTM. The mycobacteria identified in this study belonged to the MAC complex: M. avium-M. intracellulare, findings which are consistent with those reported by Molina-Gamboa et al [7], who identified these mycobacteria as the second most prevalent acid-fast bacilli isolated from HIVinfected patients in Mexico. Countries with limited resources like Mexico do not identify mycobacteria by culture and molecular techniques and because of this infections caused by NTM are under diagnosed or misdiagnosed. This study emphasizes the need for molecular identification of NTM in HIV-infected patients.

RFLP analysis based on IS6110 insertion is used to define clusters of MTb strains with identical DNA fingerprints. However, to the best of our knowledge, there have been no studies in Mexico that have used IS6110 RFLP analysis to characterize MTb strains isolated from HIV-infected patients. Using this method we showed wide genetic variability in Mexican strains (27 patterns from $48 \mathrm{MTb}$ strains). Our results are similar to those reported in countries like Tanzania where Yang et al 
[34] obtained 60 patterns from 68 MTb clinical strains and In Switzerland, where Strässle et al [35] identified 40 different patterns from 52 MTb strains isolated from $\mathrm{HIV}$-infected patients. Our findings differ from reports of the numbers of different MTb strains isolated from non-HIV population within endemic regions, where it has been shown that variability in IS6110 patterns is low [36]. The contrasting wide diversity of MTb strains from HIV-infected patients found in Tanzania, Switzerland and now in Mexico, might be explained by these patients having a deficient immune system, and thus providing the perfect habitat for the development of infection regardless of mycobacterial virulence [34].

In the present study we identified $16 \mathrm{MTb}$ strains (33.3\%) with five or fewer copies of IS6110; 10 of these (20.8\%) lacked IS6110. MTb strains with low IS6110 copy number have been more frequently isolated from Asian patients than from European patients. For example, $56 \%$ of the strains collected from India and 29 to $37.5 \%$ of the strains collected from Vietnam, Thailand and Malaysia contained five or fewer IS6110 elements $[37,38]$, whereas the frequencies of low-copy-number strains in Denmark and France were $11 \%$ and $8 \%$, respectively $[39,40]$. In the United States, analysis of strains from Texas, California, and Colorado reported $25 \%$ containing fewer than six IS6110 copies [41]. The reports of the incidence of strains with low copy number insertions from the United States are closer to the incidence of the Mexican strains isolated in our work.

In this study, $48 \mathrm{MTb}$ strains produced 21 spoligotyping patterns, while $9 \mathrm{M}$. bovis produced just 7 patterns. Quitugua et al [42] had reported the spoligotype 777776777760601 (ST137) in 63 patients from Texas, this pattern was identified in 2 strains in our study. Likewise, the octal 777776777760771 (ST119) which was identified in 89 patients who live on the border of Mexico (Tamaulipas) and United States (Texas), was identified in 3 strains in this study. Other octals found by Quitugua et al and also in our work, were 777777777760771 (ST53) and 777777607760771 (ST42), confirming that there are some strains of MTb circulating between Mexico and United States. The spoligotypes ST42, ST47, ST50 and ST53 identified in this study, have been found in others countries including Brazil, South Africa and Poland [43-45], suggesting that these strains might be circulating worldwide. Furthermore, the ST53 spoligotype has also been isolated from Egyptian mummies [46]; this spoligotype is one of the most common patterns and, according to a hypothesis about the evolution of MTb strains by loss of DRs [47], close to the origin of development of mycobacterial diversity.

The ST683 spoligotype found in M. bovis strains isolated in this study has also been found in cattle from Juarez City and Chihuahua (Mexico) [48] and has been frequently isolated from cattle in Australia, Argentina, England, France and Ireland [49-53]. The pattern of transmission of $M$. bovis to HIV-infected patients is still under study; however, the identification of the same spoligotype patterns in both cattle and HIV-infected patients indicates that, as is generally accepted, ingestion of contaminated milk or dairy products is the most probable origin of infection [31].

This study is the first in Mexico where genetic diversity of mycobacterial strains has been evaluated using MIRU-VNTR. The $48 \mathrm{MTb}$ strains investigated in this report produced 40 distinct patterns by MIRU-VNTR while $9 \mathrm{M}$. bovis strains produced 7 . Analysis of these results showed that most of these patterns were unique, consistent with other studies conducted in Singapore and Belgium, where there was wide variability in MTb strains [54,55]. As expected, most of clusters based on spoligotyping or low IS6110 copy number fingerprinting could be distinguished by MIRU-VNTR. Additionally, in strains isolated from HIV-infected patients, 4 MIRU $(4,20,23$ and 31$)$ were showed to have a different pattern compared with those occurring in the population without HIV; MIRU 4 and 31 in strains isolated from HIV-infected patients presented with low polymorphism, while those identified from individuals without HIV have a high polymorphism. By contrast, MIRU 20 and 23 of strains from HIV-infected patients have a high polymorphism, while those from individuals without HIV showed a low polymorphism [16,56,57]. These differences might be useful for the differentiation and classification of strains that can only infect HIV patients.

Some authors have found that MIRU-VNTR based on a 12-loci set (MIRU-12) format have limitations in its discriminatory power [58-60]. Recently, two MIRU-VNTR formats (MIRU-15 and MIRU-24) have been developed to improve the discriminatory power of MIRU-12 [61], and found a better discriminatory power using the set of 15-loci (MIRU-15) with $825 \mathrm{MTb}$ isolates. However, in our study, the MIRU-12 allowed us to demonstrate a high genetic diversity in mycobacterial strains belonging to the MTC; in order to get a more definitive answer to this matter, more genotyping analysis should be carried out with MTb strains from different origins.

Since all isolates were collected from HIV-infected patients, we suggest to analyze MTC strains from non $\mathrm{VIH}$-infected patients from the same region in order to enhance the significance of our results.

MDR TB is an increasing problem worldwide [62]. Infection with MDR MTb is associated with significant mortality [18], and has resulted in a number of serious outbreaks [63]. Colorimetric microplate Alamar Blue assay (MABA) assays demonstrated that all isolated $M$. bovis strains were susceptible to the antibiotics tested. On the other hand, 19 (39.6\%) isolated MTb strains were 
resistant to one or more antibiotics. These results are very close to those obtained by Peter et al [64], who demonstrated that $41 \%$ of the MTb strains isolated from patients from Baja California (Mexico) were resistant to at least one antibiotic. Our study showed that $2.1 \%$ of the strains we identified were MDR, confirming the incidence of MDR TB in Mexico already reported by the WHO [4]. The highest proportions of strains were resistant to STR, as has also been reported to be the case in Africa for both HIV-infected and patients without HIV $[65,66]$. Due to the importance of INH and RIF, which are the most effective antibiotics against $\mathrm{TB}$, we determined the mutations that lead to the selection of resistant strains in our study. Three INH-resistant strains showed a mutation AGC $\rightarrow$ ACC (Ser $\rightarrow$ Thr) at codon 315 of katG gene, a finding consistent with several studies, which have shown that this mutation is the most frequently associated with this resistance $[27,67]$. In our country, this mutation seems to be as frequent $[27,28]$, as in other countries such as Russia and Brazil [20,67]. In this study, no correlation was found between genotypic drug resistance and genotypic patterns, findings which were consistent with those previously reported for $\mathrm{MTb}$ strains isolated in both HIV-infected and non HIVinfected patients $[27,66,67]$. On the other hand, one RIFresistant isolate had a mutation GAG $\rightarrow$ TCG (Glu $\rightarrow$ Ser) at codon 469 of rpoB gene, which has not been previously described, and which should be the object for further study of other strains in Mexico.

\section{Conclusions}

This is the first molecular analysis of mycobacteria isolated from HIV-infected patients in Mexico, which describe the prevalence of different mycobacterial species in this population. Using a combination of different molecular techniques a high genetic diversity of $\mathrm{MTb}$ strains was identified. New spoligotypes and MIRUVNTR patterns as well as a novel mutation associated to RIF-resistance were found. This information will facilitate the tracking of different mycobacterial species in HIV-infected individuals, and monitoring the spread of these microorganisms, leading to more appropriate measures for $\mathrm{TB}$ control in these patients.

\section{Methods}

The present experimental research that is reported in the manuscript has been performed with the approval of the Ethical Committee of the Escuela Nacional de Ciencias Biologicas, IPN, Mexico and carried out within an ethical framework.

\section{Mycobacterial strains}

Sixty seven Mycobacterial strains were isolated from 55 HIV-infected patients at different National Health
Service hospitals in Mexico City (General Hospital of Mexico, Hospital Regional "General Ignacio Zaragoza", National Medical Center "Siglo XXI" and National Medical Center "La Raza") between January and December 2006. All patients were on treatment with antiretroviral medication and their CD4 lymphocyte counts varied from 100 to 300 cells $/ \mathrm{mm}^{3}$. According the WHO data [68], the $55 \mathrm{HIV} / \mathrm{TB}$ patients corresponded aprox. to $21 \%$ of the total patients attended in México in 2006.

Mycobateria were isolated from sputum, bronchoalveolar lavage fluid, cerebrospinal fluid, urine, bone marrow, lymph node, pleural effusion, ascitic fluid, tissue biopsy, pericardial fluid, gastric fluid. Isolation and identification of mycobacteria was carried out by the Microbiology service of each hospital using acid-fast staining (AFB)

Thirty-one (46.3\%) strains were isolated from sputum and 36 (53.7\%) from extrapulmonary clinical samples.

\section{Identification of mycobacterial species}

Mycobacterial genomic DNA was isolated by guanidinium chloride extraction [69]. The identity of the 67 isolated strains was confirmed by PCR as described previously [70]. Briefly, a multiplex PCR reaction was performed to identify the genus of Mycobacterium and $M$. bovis species, and a second PCR reaction was carried out to determine if a clinical isolate belonged to the $M$. tuberculosis complex. Nontuberculous mycobacteria (NTM) were identified by sequencing the $\mathrm{V} 2$ region of the $16 \mathrm{~S}$ rRNA gene [71], using the RAC8 primer (5'CACTGGTGCCTCCCGTAGG-3'), and ABI PRISM 310 genetic analyzer (Perkin-Elmer). All sequences were analyzed by BLAST [72].

\section{DNA fingerprinting}

Mycobacterial strains belonging to MTC were subjected to spoligotyping, MIRU-VNTR analysis, phenotypic and genotypic drug resistance tests. Only MTb strains were subsequently subjected to restriction fragment length polymorphism (RFLP) analysis.

\section{IS6110 RFLP}

IS6110 fingerprinting was performed as described previously [73]. Briefly, genomic DNA from each $\mathrm{MTb}$ isolate $(2 \mu \mathrm{g})$ was digested with PvuII. Fragments were separated by electrophoresis on agarose gels, denatured and transferred by Southern blotting to nylon membrane. Hybridization was performed with a chemiluminescence-labeled 521-bp IS6110 fragment. MTb H37Rv was used as control.

\section{Spoligotyping}

This technique was carried out as described previously [11]. The DR region was amplified using oligonucleotides DRa (5'-GGTTTTGGGTCTGACGAC-3', biotinylated) 
and DRb (5'-CCGAGAGGGGACGGAAAC'-3'). Labeled amplification products were used as a probe for hybridization with 43 synthetic spacer oligonucleotides covalently bound to a membrane (Isogen Biosciences B.M., Maarssen, The Netherlands). Each oligonucleotide corresponded to a known spacer sequence. PCR product bound after hybridization was detected by streptavidinhorseradish peroxidase-enhanced chemiluminescence (Amersham, Little Chalfont, England) according to manufacturer's instructions. Spoligotypes were reported using an octal code [74]. Analysis of spoligotypes was performed using Bionumerics software version 5.5 (Applied Maths, Kortrijk, Belgium). MTb H37Rv and M. bovis BCG were used as controls.

\section{MIRU-VNTR analysis}

MIRU-VNTR typing was performed as described previously [16]. Bacteria were resuspended in $200 \mu \mathrm{l}$ milli$\mathrm{Q}$ water, boiled for $10 \mathrm{~min}$, and cooled on ice or $5 \mathrm{~min}$. Supernatant from bacterial lysates $(2 \mu \mathrm{l})$ was added to MIRU-PCR mix $(0.1 \mu \mathrm{l}$ of HotStart Taq DNA polymerase (0.5 U) (Qiagen) with $4 \mu \mathrm{l}$ of Q-solution, $0.5 \mathrm{mM}$ each dATP, dCTP, dGTP, dTTP, $2 \mu$ l of PCR buffer, variable concentrations of each primer, and $1.5 \mathrm{mM}$ $\mathrm{MgCl}_{2}$ ) in $20 \mu \mathrm{l}$ final volume. The oligonucleotides used corresponded to the flanking regions of the 12 polymorphic MIRU-VNTR loci identified in the M. tuberculosis H37Rv genome as described by Supply et al [75]. PCR reactions were performed in a PXE0.2 thermo cycler (Thermo Electron Corporation) following a protocol of: $95^{\circ} \mathrm{C}$ for $15 \mathrm{~min}$, followed by 40 cycles of $94^{\circ} \mathrm{C}$ for $1 \mathrm{~min}, 59^{\circ} \mathrm{C}$ for $1 \mathrm{~min}$, and $72^{\circ} \mathrm{C}$ for $1.5 \mathrm{~min}$, with a final extension at $72^{\circ} \mathrm{C}$ for $10 \mathrm{~min}$. PCR fragments were analyzed on a 2100 Bioanalyser (Agilent Technologies). Genotypes were expressed as numerical code representing the number of MIRU-VNTR in each loci. A dendrogram was constructed by the unweighted-pair group method using average linkages (UPGMA) after pairwise comparison of strains by calculation of the Jaccard index.

\section{Phenotypic drug resistance testing (PDRT)}

Strains were tested for PDR by colorimetric microplate Alamar Blue assay (MABA) in 96-well flat-bottom plates (Nunc International, Rochester, NY, USA) as described by Franzblau et al [76], with some modifications [77]. Briefly, cultures in exponential growth phase were diluted with sterile Middlebrook 7H9 broth supplemented with $10 \%$ OADC (oleate-albumin-dextrose-catalase) until they reached McFarland tube no. 1 turbidity, then further diluted 1:10. Streptomycin (STR), isoniazid (INH), ethambutol (EMB) and rifampin (RIF) were obtained from Sigma Chemical (USA). One hundred microliters of MTb inoculum was incubated in medium without drug or with drugs in the following concentration ranges: INH, 1 to $0.031 \mu \mathrm{g} / \mathrm{ml}$; RIF, 2 to $0.062 \mu \mathrm{g} /$ $\mathrm{ml}$; STR, 8 to $0.25 \mu \mathrm{g} / \mathrm{ml}$; and EMB, 32 to $1 \mu \mathrm{g} / \mathrm{ml}$. Following incubation for 5 days at $37^{\circ} \mathrm{C}$ indicator solution $(20 \mu \mathrm{l}$ of Alamar Blue [Trek, OH, USA] and $12 \mu \mathrm{l}$ of sterile $10 \%$ Tween 80 ) was added to control inoculi without drugs and plates were incubated at $37^{\circ} \mathrm{C}$ for a further $24 \mathrm{~h}$. If the medium in control inoculi turned pink, subsequently indicator solution was added to inoculi that had been incubated with drugs and after 24 $\mathrm{h}$ incubation the colour of all the samples was recorded. Wells remaining blue were scored as "negative growth". The minimal inhibitory concentration (MIC) was defined as the lowest drug concentration that prevented colour change. If by day 6 no change was recorded in the drug-free control, the plate was incubated for a further 3 days; if control inoculi were still negative, a second control inoculum was used (day 9) and the whole procedure was repeated. MTb H37Rv was included as control strain. An isolate was considered drug resistant when the MIC was higher than $0.25 \mu \mathrm{g} /$ $\mathrm{ml}$ for INH, $0.25 \mu \mathrm{g} / \mathrm{ml}$ for RIF, $2.0 \mu \mathrm{g} / \mathrm{ml}$ for STR, and $8 \mu \mathrm{g} / \mathrm{ml}$ for EMB [77]. Multidrug resistance (MDR) was defined in accordance with standard criteria of resistance to both INH and RIF at least.

\section{Genotypic drug resistance testing}

Multiplex PCR [78] was used to detect the AGC $\rightarrow$ ACC (serine to threonine) mutation in codon 315 of the katG gene (primers: katg0F 5'-GCAGATGGGGCTGATCTACG-3' and R315 mut 5'-TCCATACGACCTCGATGCCAG-3') and to detect -15 C-to-T and -14 G-to-A substitutions (primers: mabAF 5'-CGAAGTGTGCTGAGTCACACCG-3' and inhARmut 5'-AGTCACCCCGACAACCTATTA-3') within the promoter region of the mabA-inhA operon. Following PCR, DNA from resistant strains with these mutations yielded 296bp and/or 146-bp PCR products. Bacterial DNA (50-100 ng) was used as a template in PCR reactions with pureTaq Ready-To-Go PCR bead kit (Amersham Biosciences, Piscataway, N.J.). The PCR mix consisted of 10 $\mathrm{mM}$ Tris- $\mathrm{HCl}$ (pH 9), $50 \mathrm{mM} \mathrm{KCl}, 1.5 \mathrm{mM} \mathrm{MgCl}_{2}$, a $200 \mu \mathrm{M}$ of each deoxynucleotide, $2.5 \mathrm{U}$ of pure Taq DNA polymerase and PCR primers $(200 \mathrm{mM}$ for kat $\mathrm{G}$ and $400 \mathrm{mM}$ for mabA-inhA) in a final volume of $25 \mu \mathrm{l}$. Reactions were performed in a PXE0.2 thermo cycler (Thermo Electron Corporation) starting with a $5 \mathrm{~min}$ denaturation at $95^{\circ} \mathrm{C}$, followed by 30 cycles of $95^{\circ} \mathrm{C}$ for $1 \mathrm{~min}, 68^{\circ} \mathrm{C}$ for $1 \mathrm{~min}$ and $72^{\circ} \mathrm{C}$ for $45 \mathrm{~s}$, with a final extension at $72^{\circ} \mathrm{C}$ for $10 \mathrm{~min}$. PCR products were resolved by electrophoresis in $2 \%$ agarose gels and detected by staining with ethidium bromide.

Rifampin resistant isolates were detected by amplification of a $437 \mathrm{bp}$ fragment incorporating the 
rpoB-hotspot region from bacterial DNA using primers rpoB-F1 and rpoB-R1 as described previously [25]. PCR products were sequenced using a 310 ABI PRISM sequencer (Applied Biosystems). Sequences were compared to the sequence of the rpoB-hotspot from wildtype bacteria using BLAST [72].

\section{Acknowledgements}

We thank Dr Mildred Foster, PhD, for helpful review of the manuscript and Alberto Cebollada (Zaragoza, Spain) for his help with spoligotyping analysis. This work was supported by CONACyT, Mexico, grant 2006-P60954 (JFC-C), Network 07RT0311 Program CYTED Spain (SS and JAG-y-M), and European Community, grant No. HEALTH-F3-2008-200999. It was also in part supported by IPN, SIP, grants No. 20090084 and 20091259. JFC-C, SR-G and JAG-y-M are fellows of COFAA and EDI, IPN, Mexico.

\section{Author details}

${ }^{1}$ Hospital Regional "General Ignacio Zaragoza", Mexico City, Mexico. ${ }^{2}$ Departamento de Microbiologia, ENCB-IPN, Mexico City, Mexico. ${ }^{3}$ Instituto Nacional de Ciencias Medicas y Nutricion "Salvador Zubiran", Mexico City, Mexico. ${ }^{4}$ Hospital Universitario Miguel Servet, Instituto Aragones de Ciencias de la Salud, Centro de Investigación Biomédica en Red Enfermedades Respiratorias, Zaragoza, España.

\section{Authors' contributions}

Conceived and designed the experiments: JFC-C, JAG-y-M. Performed the experiments: RL-A, CB-L, IC-R, SR-G, ACH-R, DA. Analyzed the data: JFC-C, RHP, SS, JAG-y-M. Write the paper: JFC-C, SS, JAG-y-M. All Authors have read and approved the final manuscript.

Received: 24 November 2009 Accepted: 17 March 2010 Published: 17 March 2010

\section{References}

1. 2008 Report on the global AIDS epidemic. [http://www.unaids.org/en/ KnowledgeCentre/HIVData/GlobalReport/2008/2008_Global_report.asp]

2. TB/HIV Facts 2009. [http://www.who.int/tb/challenges/hiv/ factsheet_hivtb_2009.pdf].

3. TB/HIV Facts 2008. http://www.who.int/tb/challenges/hiv/tbhiv_facts08_en. pdf.

4. TB country profile: Mexico. [http://apps.who.int/globalatlas/ predefinedReports/TB/PDF_Files/mex.pdf].

5. Dhungana GP, Ghimire P, Sharma S, Rijal BP: Characterization of mycobacteria in HIV/AIDS patients of Nepal. JNMA J Nepal Med Assoc 2008, 47:18-23.

6. Murcia-Aranguren MI, Gomez-Marin JE, Alvarado FS, Bustillo JG, de Mendivelson E, Gomez B, León Cl, Triana WA, Vargas EA, Rodríguez E: Frequency of tuberculous and non-tuberculous mycobacteria in HIV infected patients from Bogota, Colombia. BMC Infect Dis 2001, 1:21.

7. Molina-Gamboa JD, Ponce-de-Leon S, Sifuentes-Osornio J, Bobadilla del Valle M, Ruiz-Palacios GM: Mycobacterial infection in Mexican AIDS patients. J Acquir Immune Defic Syndr Hum Retrovirol 1996, 11:53-58.

8. Barnes PF, Cave MD: Molecular epidemiology of tuberculosis. N Engl J Med 2003, 349:1149-1156.

9. Agerton T, Valway S, Gore B, Pozsik C, Plikaytis B, Woodley C, Onorato I: Transmission of a highly drug-resistant strain (strain W1) of Mycobacterium tuberculosis. Community outbreak and nosocomial transmission via a contaminated bronchoscope. JAMA 1997, 278:1073-1077.

10. Bock NN, Mallory JP, Mobley N, DeVoe B, Taylor BB: Outbreak of tuberculosis associated with a floating card game in the rural south: lessons for tuberculosis contact investigations. Clin Infect Dis 1998, 27:1221-1226.

11. Kamerbeek J, Schouls L, Kolk A, van Agterveld M, van Soolingen D, Kuijper S, Bunschoten A, Molhuizen H, Shaw R, Goyal M, van Embden J: Simultaneous detection and strain differentiation of Mycobacterium tuberculosis for diagnosis and epidemiology. J Clin Microbiol 1997, 35:907-914.
12. Gibson AL, Huard RC, Gey van Pittius NC, Lazzarini LC, Driscoll J, Kurepina N, Zozio T, Sola C, Spindola SM, Kritski AL, Fitzgerald D, Kremer K, Mardassi H, Chitale P, Brinkworth J, Garcia de Viedma D, Gicquel B, Pape JW, van Soolingen D, Kreiswirth BN, Warren RM, van Helden PD, Rastogi N, Suffys PN, Lapa e Silva J, Ho JL: Application of sensitive and specific molecular methods to uncover global dissemination of the major RDRio Sublineage of the Latin American-Mediterranean Mycobacterium tuberculosis spoligotype family. J Clin Microbiol 2008, 46:1259-1267.

13. Sebban M, Mokrousov I, Rastogi N, Sola C: A data-mining approach to spacer oligonucleotide typing of Mycobacterium tuberculosis. Bioinformatics 2002, 18:235-243.

14. Frothingham R, Meeker-O'Connell WA: Genetic diversity in the Mycobacterium tuberculosis complex based on variable numbers of tandem DNA repeats. Microbiology 1998, 144:1189-1196.

15. Skuce RA, McCorry TP, McCarroll JF, Roring SM, Scott AN, Brittain D, Hughes SL, Hewinson RG, Neill SD: Discrimination of Mycobacterium tuberculosis complex bacteria using novel VNTR-PCR targets. Microbiology 2002, 148:519-528.

16. Supply P, Lesjean S, Savine E, Kremer K, van Soolingen D, Locht C: Automated high-throughput genotyping for study of global epidemiology of Mycobacterium tuberculosis based on mycobacterial interspersed repetitive units. J Clin Microbiol 2001, 39:3563-3571.

17. Blackwood KS, Wolfe JN, Kabani AM: Application of mycobacterial interspersed repetitive unit typing to Manitoba tuberculosis cases: can restriction fragment length polymorphism be forgotten? J Clin Microbiol 2004, 42:5001-5006.

18. Pablos-Mendez A, Raviglione MC, Laszlo A, Binkin N, Rieder HL, Bustreo F Cohn DL, Lambregts-van Weezenbeek CS, Kim SJ, Chaulet P, Nunn P: Global surveillance for antituberculosis-drug resistance, 1994-1997. World Health Organization-International Union against Tuberculosis and Lung Disease Working Group on Anti-Tuberculosis Drug Resistance Surveillance. N Engl J Med 1998, 338:1641-1649.

19. Davies PD: The world-wide increase in tuberculosis: how demographic changes, HIV infection and increasing numbers in poverty are increasing tuberculosis. Ann Med 2003, 35:235-243.

20. Narvskaya O, Otten T, Limeschenko E, Sapozhnikova N, Graschenkova O, Steklova L, Nikonova A, Filipenko ML, Mokrousov I, Vyshnevskiy B: Nosocomial outbreak of multidrug-resistant tuberculosis caused by a strain of Mycobacterium tuberculosis W-Beijing family in St. Petersburg, Russia. Eur J Clin Microbiol Infect Dis 2002, 21:596-602.

21. Stoeckle MY, Guan L, Riegler N, Weitzman I, Kreiswirth B, Kornblum J, Laraque F, Riley LW: Catalase-peroxidase gene sequences in isoniazidsensitive and -resistant strains of Mycobacterium tuberculosis from New York City. J Infect Dis 1993, 168:1063-1065.

22. Zhang Y, Heym B, Allen B, Young D, Cole S: The catalase-peroxidase gene and isoniazid resistance of Mycobacterium tuberculosis. Nature 1992, 358:591-593.

23. Banerjee A, Dubnau E, Quemard A, Balasubramanian V, Um KS, Wilson T, Collins D, de Lisle G, Jacobs WR Jr: inh A, a gene encoding a target for isoniazid and ethionamide in Mycobacterium tuberculosis. Science 1994, 263:227-230.

24. Heym B, Honore N, Truffot-Pernot C, Banerjee A, Schurra C, Jacobs WR Jr, van Embden JD, Grosset JH, Cole ST: Implications of multidrug resistance for the future of short-course chemotherapy of tuberculosis: a molecular study. Lancet 1994, 344:293-298.

25. Zanden Van Der AG, Te Koppele-Vije EM, Vijaya Bhanu N, Van Soolingen D, Schouls LM: Use of DNA extracts from Ziehl-Neelsen-stained slides for molecular detection of rifampin resistance and spoligotyping of Mycobacterium tuberculosis. J Clin Microbiol 2003, 41:1101-1108,

26. Brudey K, Driscoll JR, Rigouts L, Prodinger WM, Gori A, Al-Hajoj SA, Allix C, Aristimuño L, Arora J, Baumanis V, Binder L, Cafrune P, Cataldi A, Cheong S, Diel R, Ellermeier C, Evans JT, Fauville-Dufaux M, Ferdinand S, Garcia de Viedma D, Garzelli C, Gazzola L, Gomes HM, Guttierez MC, Hawkey PM, van Helden PD, Kadival GV, Kreiswirth BN, Kremer K, Kubin M, Kulkarni SP, Liens B, Lillebaek T, Ho ML, Martin C, Martin C, Mokrousov I, Narvskaïa O, Ngeow YF, Naumann L, Niemann S, Parwati I, Rahim Z, RasolofoRazanamparany V, Rasolonavalona T, Rossetti ML, Rüsch-Gerdes S, Sajduda A, Samper S, Shemyakin IG, Singh UB, Somoskovi A, Skuce RA, van Soolingen D, Streicher EM, Suffys PN, Tortoli E, Tracevska T, Vincent V, Victor TC, Warren RM, Yap SF, Zaman K, Portaels F, Rastogi N, Sola C: Mycobacterium tuberculosis complex genetic diversity: mining the fourth 
international spoligotyping database (SpolDB4) for classification, population genetics and epidemiology. BMC Microbiol 2006, 6:23.

27. Ramaswamy SV, Dou SJ, Rendon A, Yang Z, Cave MD, Graviss EA: Genotypic analysis of multidrug-resistant Mycobacterium tuberculosis isolates from Monterrey, Mexico. J Med Microbiol 2004, 53:107-113.

28. Viader-Salvado JM, Luna-Aguirre CM, Reyes-Ruiz JM, Valdez-Leal R, del Bosque-Moncayo Mde L, Tijerina-Menchaca R, Guerrero-Olazarán M: Frequency of mutations in rpo B and codons 315 and 463 of katG in rifampin- and/or isoniazid-resistant Mycobacterium tuberculosis isolates from northeast Mexico. Microb Drug Resist 2003, 9:33-38.

29. Perez-Martinez I, Ponce-De-Leon A, Bobadilla M, Villegas-Sepulveda N, Perez-Garcia M, Sifuentes-Osornio J, González-y-Merchand JA, EstradaGarcía T: A novel identification scheme for genus Mycobacterium, $M$. tuberculosis complex, and seven mycobacteria species of human clinical impact. Eur J Clin Microbiol Infect Dis 2008, 27:451-459.

30. Global tuberculosis control 2009. Epidemiology strategy financing. http://www.who.int/tb/publications/global_report/2009/pdf/full_report.pdf.

31. Cosivi O, Grange JM, Daborn CJ, Raviglione MC, Fujikura T, Cousins D, Robinson RA, Huchzermeyer HF, de Kantor I, Meslin FX: Zoonotic tuberculosis due to Mycobacterium bovis in developing countries. Emerg Infect Dis 1998, 4:59-70.

32. Cicero R, Olivera H, Hernandez-Solis A, Ramirez-Casanova E, EscobarGutierrez A: Frequency of Mycobacterium bovis as an etiologic agent in extrapulmonary tuberculosis in HIV-positive and -negative Mexican patients. Eur J Clin Microbiol Infect Dis 2009, 28:455-460.

33. Piersimoni C, Scarparo C: Pulmonary infections associated with nontuberculous mycobacteria in immunocompetent patients. Lancet Infect Dis 2008, 8:323-334.

34. Yang ZH, Mtoni I, Chonde M, Mwasekaga M, Fuursted K, Askgard DS, Bennedsen J, de Haas PE, van Soolingen D, van Embden JD, Andersen AB: DNA fingerprinting and phenotyping of Mycobacterium tuberculosis isolates from human immunodeficiency virus (HIV)-seropositive and HIVseronegative patients in Tanzania. J Clin Microbiol 1995, 33:1064-1069.

35. Strassle A, Putnik J, Weber R, Fehr-Merhof A, Wust J, Pfyffer GE: Molecular epidemiology of Mycobacterium tuberculosis strains isolated from patients in a human immunodeficiency virus cohort in Switzerland. J Clin Microbiol 1997, 35:374-378.

36. van Soolingen D, de Haas PE, Hermans PW, Groenen PM, van Embden JD: Comparison of various repetitive DNA elements as genetic markers for strain differentiation and epidemiology of Mycobacterium tuberculosis. J Clin Microbiol 1993, 31:1987-1995.

37. Das S, Paramasivan CN, Lowrie DB, Prabhakar R, Narayanan PR: IS 6110 restriction fragment length polymorphism typing of clinical isolates of Mycobacterium tuberculosis from patients with pulmonary tuberculosis in Madras, south India. Tuber Lung Dis 1995, 76:550-554.

38. Park YK, Bai GH, Kim SJ: Restriction fragment length polymorphism analysis of Mycobacterium tuberculosis isolated from countries in the western pacific region. J Clin Microbiol 2000, 38:191-197.

39. Bauer J, Andersen AB, Kremer K, Miorner $\mathrm{H}$ : Usefulness of spoligotyping to discriminate IS 6110 low-copy-number Mycobacterium tuberculosis complex strains cultured in Denmark. J Clin Microbiol 1999, 37:2602-2606.

40. Gutierrez MC, Vincent V, Aubert D, Bizet J, Gaillot O, Lebrun L, Le Pendeven C, Le Pennec MP, Mathieu D, Offredo C, Pangon B, PierreAudigier C: Molecular fingerprinting of Mycobacterium tuberculosis and risk factors for tuberculosis transmission in Paris, France, and surrounding area. J Clin Microbiol 1998, 36:486-492.

41. Yang Z, Barnes PF, Chaves F, Eisenach KD, Weis SE, Bates JH, Cave MD: Diversity of DNA fingerprints of Mycobacterium tuberculosis isolates in the United States. J Clin Microbiol 1998, 36:1003-1007.

42. Quitugua TN, Seaworth BJ, Weis SE, Taylor JP, Gillette JS, Rosas II, Jost Jr, KC Jr, Magee DM, Cox RA: Transmission of drug-resistant tuberculosis in Texas and Mexico. J Clin Microbiol 2002, 40:2716-2724.

43. Borsuk S, Dellagostin MM, Madeira S de G, Lima C, Boffo M, Mattos I, Almeida da Silva PE, Dellagostin OA: Molecular characterization of Mycobacterium tuberculosis isolates in a region of Brazil with a high incidence of tuberculosis. Microbes Infect 2005, 7:1338-1344.

44. Stavrum R, Mphahlele M, Ovreas K, Muthivhi T, Fourie PB, Weyer K, Grewal HM: High diversity of Mycobacterium tuberculosis genotypes in South Africa and preponderance of mixed infections among ST53 isolates. J Clin Microbiol 2009, 47:1848-1856.
45. Augustynowicz-Kopec E, Jagielski T, Zwolska Z: Genetic diversity of isoniazid-resistant Mycobacterium tuberculosis isolates collected in Poland and assessed by spoligotyping. J Clin Microbiol 2008 46:4041-4044.

46. Zink AR, Sola C, Reischl U, Grabner W, Rastogi N, Wolf H, Nerlich AG: Characterization of Mycobacterium tuberculosis complex DNAs from Egyptian mummies by spoligotyping. J Clin Microbiol 2003, 41:359-367.

47. van Embden JD, van Gorkom T, Kremer K, Jansen R, Zeijst van Der BA, Schouls LM: Genetic variation and evolutionary origin of the direct repeat locus of Mycobacterium tuberculosis complex bacteria. J Bacteriol 2000, 182:2393-2401

48. Cobos-Marin L, Montes-Vargas J, Zumarraga M, Cataldi A, Romano Ml, Estrada-Garcia I, Gonzalez-y-Merchand JA: Spoligotype analysis of Mycobacterium bovis isolates from Northern Mexico. Can J Microbiol 2005, 51:996-1000

49. Cousins D, Williams S, Liebana E, Aranaz A, Bunschoten A, Van Embden J, Ellis T: Evaluation of four DNA typing techniques in epidemiological investigations of bovine tuberculosis. J Clin Microbiol 1998, 36:168-178.

50. Zumarraga MJ, Martin C, Samper S, Alito A, Latini O, Bigi F, Roxo E, Cicuta ME, Errico F, Ramos MC, Cataldi A, van Soolingen D, Romano M! Usefulness of spoligotyping in molecular epidemiology of Mycobacterium bovis-related infections in South America. J Clin Microbiol 1999, 37:296-303.

51. Gibson AL, Hewinson G, Goodchild T, Watt B, Story A, Inwald J, Drobniewski FA: Molecular epidemiology of disease due to Mycobacterium bovis in humans in the United Kingdom. J Clin Microbiol 2004, 42:431-434.

52. Haddad N, Ostyn A, Karoui C, Masselot M, Thorel MF, Hughes SL, Inwald J, Hewinson RG, Durand B: Spoligotype diversity of Mycobacterium bovis strains isolated in France from 1979 to 2000. J Clin Microbiol 2001, 39:3623-3632.

53. Costello E, O'Grady D, Flynn O, O'Brien R, Rogers M, Quigley F, Egan J, Griffin J: Study of restriction fragment length polymorphism analysis and spoligotyping for epidemiological investigation of Mycobacterium bovis infection. J Clin Microbiol 1999, 37:3217-3222.

54. Sun YJ, Bellamy R, Lee AS, Ng ST, Ravindran S, Wong SY, Locht C, Supply P, Paton NI: Use of mycobacterial interspersed repetitive unit-variablenumber tandem repeat typing to examine genetic diversity of Mycobacterium tuberculosis in Singapore. J Clin Microbiol 2004, 42:1986-1993.

55. Allix C, Walravens K, Saegerman C, Godfroid J, Supply P, Fauville-Dufaux M: Evaluation of the epidemiological relevance of variable-number tandemrepeat genotyping of Mycobacterium bovis and comparison of the method with 156110 restriction fragment length polymorphism analysis and spoligotyping. J Clin Microbiol 2006, 44:1951-1962.

56. Drobniewski F, Balabanova Y, Nikolayevsky V, Ruddy M, Kuznetzov S, Zakharova S, Melentyev A, Fedorin I: Drug-resistant tuberculosis, clinical virulence, and the dominance of the Beijing strain family in Russia. JAMA 2005, 293:2726-2731.

57. Savine E, Warren RM, Spuy van der GD, Beyers N, van Helden PD, Locht C, Supply $P$ : Stability of variable-number tandem repeats of mycobacterial interspersed repetitive units from 12 loci in serial isolates of Mycobacterium tuberculosis. J Clin Microbiol 2002, 40:4561-4566.

58. Alonso-Rodriguez N, Martinez-Lirola M, Herranz M, Sanchez-Benitez M, Barroso P, Bouza E, García de Viedma D: Evaluation of the new advanced 15-loci MIRU-VNTR genotyping tool in Mycobacterium tuberculosis molecular epidemiology studies. BMC Microbiol 2008, 8:34.

59. Scott AN, Menzies D, Tannenbaum TN, Thibert L, Kozak R, Joseph $L$, Schwartzman K, Behr MA: Sensitivities and specificities of spoligotyping and mycobacterial interspersed repetitive unit-variable-number tandem repeat typing methods for studying molecular epidemiology of tuberculosis. J Clin Microbiol 2005, 43:89-94.

60. van Deutekom H, Supply P, de Haas PE, Willery E, Hoijng SP, Locht C, Coutinho RA, van Soolingen D: Molecular typing of Mycobacterium tuberculosis by mycobacterial interspersed repetitive unit-variablenumber tandem repeat analysis, a more accurate method for identifying epidemiological links between patients with tuberculosis. J Clin Microbiol 2005, 43:4473-4479.

61. Supply P, Allix C, Lesjean $\mathrm{S}$, Cardoso-Oelemann M, Rusch-Gerdes S, Willery E, Savine E, de Haas P, van Deutekom H, Roring S, Bifani P, Kurepina N, Kreiswirth B, Sola C, Rastogi N, Vatin V, Gutierrez MC, Fauville M, Niemann S, 
Skuce R, Kremer K, Locht C, van Soolingen D: Proposal for standardization of optimized mycobacterial interspersed repetitive unit-variable-number tandem repeat typing of Mycobacterium tuberculosis. I Clin Microbiol 2006, 44:4498-510.

62. Varma-Basil M, El-Hajj H, Colangeli R, Hazbon MH, Kumar S, Bose M, Bobadilla-del-Valle M, García LG, Hernández A, Kramer FR, Osornio JS, Ponce-de-León A, Alland D: Rapid detection of rifampin resistance in Mycobacterium tuberculosis isolates from India and Mexico by a molecular beacon assay. J Clin Microbiol 2004, 42:5512-5516.

63. Frieden TR, Sherman LF, Maw KL, Fujiwara PI, Crawford JT, Nivin B, Sharp V, Hewlett D Jr, Brudney K, Alland D, Kreisworth BN: A multi-institutional outbreak of highly drug-resistant tuberculosis: epidemiology and clinical outcomes. JAMA 1996, 276:1229-1235.

64. Peter CR, Schultz E, Moser K, Cox M, Freeman R, Ramirez-Zetina M, Lomeli MR: Drug-resistant pulmonary tuberculosis in the Baja CaliforniaSan Diego County border population. West J Med 1998, 169:208-213.

65. Bruchfeld J, Aderaye G, Palme IB, Bjorvatn B, Ghebremichael S, Hoffner S, Lindquist L: Molecular epidemiology and drug resistance of Mycobacterium tuberculosis isolates from Ethiopian pulmonary tuberculosis patients with and without human immunodeficiency virus infection. J Clin Microbiol 2002, 40:1636-1643.

66. Kibiki GS, Mulder B, Dolmans WM, de Beer JL, Boeree M, Sam N, van Soolingen D, Sola C, Zanden van der AG: M. tuberculosis genotypic diversity and drug susceptibility pattern in HIV-infected and non-HIVinfected patients in northern Tanzania. BMC Microbiol 2007, 7:51.

67. Hofling CC, Pavan EM, Giampaglia CM, Ferrazoli L, Aily DC, de Albuquerque DM, Ramos MC: Prevalence of kat G Ser315 substitution and $r$ roB mutations in isoniazid-resistant Mycobacterium tuberculosis isolates from Brazil. Int J Tuberc Lung Dis 2005, 9:87-93.

68. Global tuberculosis control 2008. Surveillance planning financing. [http:// www.who.int/tb/publications/global_report/2008/pdf/fullreport.pdf].

69. Gonzalez-y-Merchand JA, Estrada-Garcia I, Colston MJ, Cox RA: A novel method for the isolation of mycobacterial DNA. FEMS MicrobiolLett 1996, 135:71-77.

70. Cobos-Marin L, Montes-Vargas J, Rivera-Gutierrez S, Licea-Navarro A, Gonzalez-y-Merchand JA, Estrada-Garcia I: A novel multiplex-PCR for the rapid identification of Mycobacterium bovis in clinical isolates of both veterinary and human origin. Epidemiol Infect 2003, 130:485-490.

71. Kirschner P, Bottger EC: Species identification of mycobacteria using rDNA sequencing. Methods Mol Biol 1998, 101:349-361.

72. Altschul SF, Gish W, Miller W, Myers EW, Lipman DJ: Basic local alignment search tool. J Mol Biol 1990, 215:403-410.

73. van Embden JD, Cave MD, Crawford JT, Dale JW, Eisenach KD, Gicquel B, Hermans P, Martin C, McAdam R, Shinnick TM, Small PM: Strain identification of Mycobacterium tuberculosis by DNA fingerprinting: recommendations for a standardized methodology. J Clin Microbiol 1993, 31:406-409.

74. Dale JW, Brittain D, Cataldi AA, Cousins D, Crawford JT, Driscoll J, Heersma H, Lillebaek T, Quitugua T, Rastogi N, Skuce RA, Sola C, Van Soolingen D, Vincent V: Spacer oligonucleotide typing of bacteria of the Mycobacterium tuberculosis complex: recommendations for standardised nomenclature. Int J Tuberc Lung Dis 2001, 5:216-219.

75. Supply P, Mazars E, Lesjean S, Vincent V, Gicquel B, Locht C: Variable human minisatellite-like regions in the Mycobacterium tuberculosis genome. Mol Microbiol 2000, 36:762-771.

76. Franzblau SG, Witzig RS, McLaughlin JC, Torres P, Madico G, Hernandez A, Degnan MT, Cook MB, Quenzer VK, Ferguson RM, Gilman RH: Rapid, lowtechnology MIC determination with clinical Mycobacterium tuberculosis isolates by using the microplate Alamar Blue assay. J Clin Microbiol 1998, 36:362-366.

77. Luna-Herrera J, Martinez-Cabrera G, Parra-Maldonado R, Enciso-Moreno JA Torres-Lopez J, Quesada-Pascual F, Delgadillo-Polanco R, Franzblau SG: Use of receiver operating characteristic curves to assess the performance of a microdilution assay for determination of drug susceptibility of clinical isolates of Mycobacterium tuberculosis. Eur J Clin Microbiol Infect Dis 2003, 22:21-27.

78. Herrera-Leon L, Molina T, Saiz P, Saez-Nieto JA, Jimenez MS: New multiplex PCR for rapid detection of isoniazid-resistant Mycobacterium tuberculosis clinical isolates. Antimicrob Agents Chemother 2005, 49:144-147. doi:10.1186/1471-2180-10-82

Cite this article as: Lopez-Alvarez et al:: First insights into the genetic diversity of Mycobacterium tuberculosis isolates from HIV-infected Mexican patients and mutations causing multidrug resistance. $B M C$ Microbiology 2010 10:82.

\section{Submit your next manuscript to BioMed Central and take full advantage of:}

- Convenient online submission

- Thorough peer review

- No space constraints or color figure charges

- Immediate publication on acceptance

- Inclusion in PubMed, CAS, Scopus and Google Scholar

- Research which is freely available for redistribution

Submit your manuscript at www.biomedcentral.com/submit
Biomed Central 